University of Wollongong

Research Online

Faculty of Informatics - Papers (Archive)

Faculty of Engineering and Information

Sciences

November 2007

\title{
Can Superior CRM Capabilities Improve Performance in Banking
}

T. R. Coltman

University of Wollongong, tcoltman@uow.edu.au

Follow this and additional works at: https://ro.uow.edu.au/infopapers

Part of the Physical Sciences and Mathematics Commons

\section{Recommended Citation}

Coltman, T. R.: Can Superior CRM Capabilities Improve Performance in Banking 2007.

https://ro.uow.edu.au/infopapers/581

Research Online is the open access institutional repository for the University of Wollongong. For further information contact the UOW Library: research-pubs@uow.edu.au 


\title{
Can Superior CRM Capabilities Improve Performance in Banking
}

\author{
Abstract \\ The market enthusiasm generated around investment in customer relationship management (CRM) \\ technology is in stark contrast to the nay-saying by many academic and business commentators. This \\ raises an important research question concerning the extent to which banks should continue to invest in \\ CRM technology. Drawing on field interviews and a survey of senior bank executives the results reveal \\ that a superior CRM capability can deliver improved performance. The paper then demonstrates that in \\ order to be most successful, CRM programs require a combination of technical, human and business \\ capabilities.

\section{Keywords} \\ Studies, Customer relationship management, Banking industry, Competitive advantage, Market strategy, \\ Capital investments, Technological planning, Models, Relationship marketing, Quality of service, Bank \\ services \\ Disciplines \\ Physical Sciences and Mathematics

\section{Publication Details} \\ This article was originally published as Coltman, TR, Can Superior CRM Capabilities Improve Performance \\ in Banking, Journal of Financial Services Marketing, 2007, 12(2), 102-114. The definitive publisher- \\ authenticated version is available online here.
}




\title{
Can Superior CRM Capabilities Improve Performance in Banking
}

\author{
Tim Coltman \\ Centre for Business Services Science, \\ School of Information Systems and Technology, \\ University of Wollongong, \\ NSW, Australia
}

Correspondence:

Tim Coltman, University of Wollongong, Northfields Rd, Wollongong, NSW, 2522 Australia Tel: +61 (2) 42213912 (phone)

Fax: +61 (2) 93137279 (fax)

E-mail: tim_coltman@uow.edu.au

Tim Coltman is Director, Centre for Business Services Science, University of Wollongong, Australia. He has published in journals such as California Management Review, Journal of Information Technology, Advances in Strategy and Communications of the ACM. He currently holds an Australian Research Council Fellowship where he is engaged in pioneer supply chain management research for DHL and BlueScope Steel. Previously, he has completed research projects in customer relationship management for organizations such as the SAS Institute, SAP, Fairfax Business Research and MIS magazine. 


\title{
Can Superior CRM Capabilities Improve Performance in Banking?
}

\begin{abstract}
The market enthusiasm generated around investment in CRM technology is in stark contrast to the nay-saying by many academic and business commentators. This raises an important research question concerning the extent to which banks should continue to invest in CRM technology. Drawing on field interviews and a survey of senior bank executives the results reveal that a superior CRM capability can deliver improved performance. The paper then demonstrates that in order to be most successful, CRM programs require a combination of technical, human and business capabilities.
\end{abstract}

Keywords: CRM, capabilities, performance 


\section{INTRODUCTION}

The ability to identify profitable customers and then customize marketing on the basis of customer value has enabled many banks to punch above their weight in today's competitive environment. A number of stellar examples come to mind: National Australia Bank in Australia, Bank of Montreal in Canada and Capital One in the U.S. In each case, these banks have chosen to compete through superior customer relating capabilities based largely on the CRM programs deployed. ${ }^{(1,2)}$ It will come as no surprise that vendors are quick to point out that by allocating resources to customer relationship management (CRM) technologies all firms in the financial services sector can generate new forms of competitive advantage.

However, the enthusiasm generated around CRM and a select concentration of "relationship winners" is in stark contrast to the nay-saying by many business commentators. According to a recent study ${ }^{(3)}$ personal and retail banking in the United Kingdom is a comic story as banks continue to offer sub-standard service despite the huge investment in CRM technology. Over a quarter of these banks ( 28 per cent) failed to respond to simple customer queries and more than 60 per cent of respondents felt that banks could do much more to improve customer service standards. Far from improving profits and cementing relationships, many firms across a wide range of industry sectors (that includes banks) have found themselves in the worst case scenario; where their CRM systems wind up alienating long-term customers and employees. ${ }^{(4)}$

\section{So why should banks continue to invest in CRM programs?}

In tackling this question one should be mindful of the scholarly challenge posed by the fact that the exact meaning of CRM is still subject to a wide range of views. For example, in a series of interviews with executives, Payne and Frow ${ }^{(5)}$ found that to some, CRM meant direct mail, a 
loyalty scheme, help desk and call centre. Other executives envisioned CRM as a data warehouse, data mining, e-commerce solution or databases for sales force automation.

These differences reflect the tactical and strategic way in which CRM has been deployed. When viewed from a tactical perspective, CRM comprises functions in isolation, such as sales force automation or online campaign management. These applications provide silos of customer information based on a single view of the customer; through a particular contact channel. This can be frustrating for bank customers with a loan product and a savings product because they may need to interact with the bank for various reasons (withdrawal transaction, balance request, complaint etc.) using a variety of channels. To overcome this limitation, CRM has also been deployed at an enterprise level, or what Kumar and Reinartz ${ }^{(6)}$ term strategic CRM. According to this approach CRM is nested within an intricate organizational system of interrelated and interdependent resources that is used to generate competitive advantage. Such an approach aligns with two schools of thought underpinning resource based theory-namely the resource-based view (RBV) and the knowledge-based view (KBV)—that emphasizes firm specific competitive advantages. $^{(7)}$

As a strategic initiative, CRM is best conceptualised as a higher order capability that includes a combination of human, technical and business related activities. The reason for this is that according to RBV theory, resources that are not rare, valuable or non imitable cannot explain variance in performance. ${ }^{(8)}$ Hence, a CRM program that includes a combination of human, technical and business related activities is likely to be more valuable and costly to imitate due to the presence of isolating mechanisms such as path dependence, causal ambiguity, social complexity and interdependent skills. In other words, when these lower order resources and capabilities-none of which is independently superior-are combined into a higher order CRM capability, they can make for a more valuable and effective program. 
This interdependent reliance upon causally ambiguous factors can represent unfamiliar territory for many managers. Whenever this is the case, there is greater opportunity for managerial discretion to be seen as relevant and practically important to the final payoff..$^{(9,10)}$ Hambrick and Finkelstein ${ }^{(11)}$ were the first to introduce and elaborate on the concept of managerial discretion as a way to reconcile polar views about how much influence executives and senior managers have on organizational outcomes. Defined as the "latitude of action" their proposition was that senior decision makers vary widely in their beliefs and are therefore an important indicator to investment success.

The remaining sections set about testing a general framework of CRM performance, which explains why, and through which mechanisms, the adoption of a higher order CRM capability should lead to operational and economic advantage. The importance of these measures is examined using field interviews and a survey of 45 senior executives from the Australian banking industry. Results reveal an adroit combination of human and technological capabilities is required to successfully achieve improved performance. This finding is important as it suggests that CRM market leaders are not fooled by simplistic solutions and are prepared to invest in building a variety of capabilities to make CRM work in the banking sector.

\section{THEORETICAL BACKGROUND}

Although the term CRM first surfaced in the IT vendor and practitioner community during the mid 1990s, the customer relationship concept can be traced to the 1950s when Drucker ${ }^{(12)}$ argued that customers should be the foundation of an organization and the very reason for its existence. The link between customer-relationship activity and improved firm performance has received empirical support based on measures of stock price ${ }^{(13)}$, customer loyalty ${ }^{(13,14)}$ and market 
orientation. $^{(15)}$ However, preliminary work in this area has also been tempered by results that stress the importance of moderating effects. ${ }^{(16)}$

Although recent work has found that IT can enhance the performance of customer service processes, ${ }^{(17)}$ a common misunderstanding among academics and practitioners is that they frequently associate CRM with technology based solutions. ${ }^{(18)}$ Indeed, the negative reaction to CRM we have witnessed in the popular press appears to have more to do with the IT dependent view of the world rather than a failure to appreciate the importance of customer relationship value. $^{(6)}$ It is not surprising therefore that many CRM efforts have failed to meet initial expectations of the companies implementing them.

In recent times the information systems literature has also been quick to point out that a narrow focus on technology as a source of sustained performance-such as that recently assumed in the business press ${ }^{(19)}$-is misguided and misleading. ${ }^{(20)}$ In other words, strategic IT consists of a program of activity, dependent upon IT at its base, but encompassed within a wider system that includes human capabilities and organizational structures. This position aligns well with the RBV of the firm-a theory that has received much attention in the IT and IS literature of late ${ }^{(21-}$ 26). An illustrative example of this work has shown that market leaders are characterised by the "synergistic combination of IT resources ... with other organizational resources and capabilities." $(21: 186)$

\section{The Drivers of a Superior CRM Capability}

Drawing on recent trends in the RBV literature we hypothesize that a superior CRM capability will arise when sufficient technical, human and business related capabilities exist in the firm. For example, the resource-based view of the firm ${ }^{(8,27)}$ directs us towards the importance of technical resources such as information technology. The emergence of integrated CRM and Enterprise Resource Planning applications (e.g., SAP and 
Oracle/Siebel) and other 'best of breed' applications (e.g., NCR Teradata, Broadvision and E.piphany) are illustrative examples. The key material elements are the data repository that supports collection of customer data, and the IT systems-computer hardware, software, middleware, analysis tools and applications - that provide information from many customer contact points. Whenever these complex and highly integrated CRM applications are difficult to build and duplicate they have the potential to create sustainable competitive advantages. $^{(17)}$

Further, it is unreasonable to expect that an IT capability alone is sufficient, as the data needs to be interpreted correctly in the context of the business. The knowledge-based view-considered an outgrowth of the RBV—conceptualises the firm as an institution for integrating specialist knowledge to its members. ${ }^{(28,29)}$ According to this school of thought the primary task for CRM is to provide a program for data and information coordination that is necessary for customer knowledge creation. In other words, the insights gained from IT applications must inform the decision-making process for a sufficiently "good" decision to emerge. In this respect, the skills and know-how possessed by staff in converting data to customer knowledge is crucial to success. For example, in modern business, individuals must increasingly cope with vast amounts of rapidly changing and often conflicting market information. The effectiveness of this process is reflected in the sophistication of the employee's analytical capabilities ${ }^{(30)}$ and allows the firm to "compete on analytics". (31)

Simply gathering information through sophisticated CRM systems and gaining insight through complex human skills and experience will, understandably, have little impact on the business unless action is taken. In other words, the outputs of any CRM program have to be deployed in the wider business and although many firms may own the same basic technology and hold similar skills, few firms will possess the organisational culture required to fully exploit these resources 
and build meaningful customer relationships. This is an important premise underpinning the $\mathrm{KBV}$ as this approach is most concerned with knowledge application rather than knowledge creation.

However, there is a temptation to be normative about the pursuit of competitive advantage by directing attention and resources to particular CRM capabilities. For managers this approach is tempting because it allows them to simplify complex CRM implementations and concentrate their effort on "getting it right", one capability at a time. Yet well-developed technical, human and business capabilities in isolation are insufficient to generate competitive superiority. The primary reason is that in the case of CRM, each capability is nested within an intricate organizational system of interrelated and interdependent resources.

This does not mean that all individual capabilities must be superior to the competition. Rather, it is important to conceptualize a CRM program as a combination of activities requiring managers to concentrate not on one or two capabilities independently, but on the CRM program as a whole. In this sense, competitive superiority is likely based on a weighted average effect; the business does not rank first on any asset or capability but is better on average than any of its rivals.

Therefore, CRM programs require the orchestration of a combination variety of resources and capabilities, none of which is superior in isolation, but when combined with others, make for a better and more effective program. This line of thinking implies that a second order or "meta capability" may go a long way towards explaining improved performance. The importance of a second order CRM capability is that it enables us to capture the efficiency with which an organization uses the resources available (i.e., technology inputs and human know-how etc.), and converts them into whatever output(s) it desires (i.e., its objectives, such as developing a marketoriented position of advantage); according to Makadok ${ }^{(32)}$ this is the best way to measure 
capabilities. Such an approach allows us to hypothesize that:

$H_{1}$ : Organizations with superior CRM capability display a greater propensity to capture higher levels of performance relative to competitors.

\section{Managerial- Orientation}

The way managers perceive the environment and a company's place within it, is a cognitive factor, that has long-lasting and perpetual influence on their behaviour. ${ }^{(33-35)}$ As intuitive as this statement may appear, the role of managerial discretion has not held great influence in traditional theories of competitive advantage and is certainly not universally held. ${ }^{(36)}$ However, when a new program such as CRM is in its infancy, managers facing the same market pressures may hold very different beliefs about the likely impact that a market orientation will have on firm performance. For example, some managers may believe that CRM will enhance the effectiveness of the firm, whilst others believe it may either destroy existing competencies, enhance legitimacy in the market, or have little or no effect on current performance. This insight is theoretically supported in an emerging stream of research focused on the effects of new technologies, ${ }^{(37-39)}$ the behavior of individuals toward information technologies in particular ${ }^{(40,41)}$ and on perceptual phenomena. $^{(42)}$

A major study by Computer Sciences Corporation (CSC) Index ${ }^{(43)}$ highlights the importance of managerial beliefs. This study found a strong correlation between the level of managerial ambition and the success of reengineering change programs. CSC's research reported that reengineering programs with "breakthrough" ambitions were more likely to succeed than those with modest objectives. The authors' conclude that modest ambitions provide insufficient incentive to management to make the necessary changes in organization, processes, training and

reward systems that the programs required. A more recent McKinsey study ${ }^{(44)}$ also supports the 
view that when managers hedge their bets, they are unlikely to infuse CRM deployment with the necessary energy to modify the structures and metrics for evaluating frontline behavior. The predictable result is that CRM systems are used little or not at all. For example, in the insurance industry more than one third of the CRM modules developed during the past three years remain dormant in areas such as marketing campaign management, data analysis and opportunity management. ${ }^{(45)}$

Collectively, these findings indicate that it is not only operating capabilities that generate organizational rents, it is also difficult to predict how managers might perceive the benefits of CRM. Modest managerial beliefs, legitimacy motivations, or a general failure to view CRM as strategic, are unlikely to deliver the organizational change that CRM requires. Rather, strongly held beliefs regarding the potential for CRM are required to deal with the organizational change and implementation challenges that a CRM program presents. The following testable hypothesis is derived from this argument:

$\mathrm{H}_{2}$ : Organizations are best positioned to capture the benefits of CRM when senior managers believe strongly in the benefits of CRM.

\section{Research Model}

Explaining variation in competitive advantage by reference to different degrees and qualities of tangible and intangible capabilities has been central to the seminal theoretical contributions in marketing strategy ${ }^{(46,47)}$ and competitive advantage. ${ }^{(48,49)}$ Our study draws on this workparticularly the deterministic logic proposed by Day and Wensley ${ }^{(48)}$ — where superior resources lead to performance improvements (see Figure 1). Further, Day and Wensley's model was an important precursor to the resource based view (RBV) in strategy and has become a benchmark 
for publications in marketing that have sought to explain performance differences between companies. $^{(50)}$

\section{$<$ Insert Figure 1>}

\section{Research Method and Measures}

\section{Sample Characteristics and Data Collection}

We test the hypotheses on a sample of Australian banks. Background questions indicated that the banks selected were common in their application of CRM technology (i.e., they are moderate to heavy users), size of customer base (i.e., they have a large customer base) and exposure to market pressures to differentiate them from the competition.

On the basis of an extensive and recursive pre-testing procedure, we identified that only 2-3 members of the top management team had a complete picture of CRM relative to competitors. Hence, a competent key informant was identified as either: a marketing director, chief information officer, chief financial officer, or management executive typically at the general manager level in a strategic business unit (SBU). The business unit, rather than the firm, was used as the unit of analysis. This is appropriate because the research is primarily concerned with how components of the organization's value chain are affected by CRM. Our pilot testing interviews indicated that the way CRM programs are used by one business unit—such as Corporate and Institutional Banking — in a large bank is very different from the actions of another unit—such as Business Financial Services.

A matching procedure was used to overcome prior problems where reliance on self-report data from single informants has been criticized for the likely association between variables due to

common method bias and other cognitive biases. ${ }^{(51)}$ The matching procedure required at least two survey responses to be collected from each company. This allows one to compare measures 
of the independent variable — made by a particular respondent-from measures of the dependent variable — made by a different respondent in the same organization.

A total of 45 responses were received from financial service institutions yielding a 32 percent response rate. This sample is highly representative because it includes responses from all five major Australian banks and 21 smaller banks and building societies. The market share occupied by the banks sampled in this research exceeds 70 per cent. ${ }^{(52)}$ The mean firm studied had approximately 541 employees.

\section{Measure Development}

Performance was measured using subjective assessments of a business's performance relative to other businesses in the same industry. While there are potential reporting biases in such measures, research has shown that self reported performance data are generally reliable ${ }^{(53)}$ and represent a valid way to operationalize financial performance. ${ }^{(54)}$

Our measure of performance is based on three dimensions. First, a multidimensional and balanced assessment of performance is developed based on the balanced scorecard. ${ }^{(55)}$ Three different dimensions of performance captured are: (1) return on investment after tax; (2) new product revenue generation, and (3) sales growth. Second, to develop some sense of comparativeness we required respondents to assess performance relative to that enjoyed by key competitors. ${ }^{(56)}$ This is important because, taken in isolation, an organization's performance, whether strong or weak, contains only limited meaning. Third, all individual assessments of performance were based on the "last three years". This is necessary to overcome quarterly reporting practices that may fluctuate widely across any given time period.

To develop the second order construct - superior CRM capability - an approach similar to Marchand, Kettinger et al.'s ${ }^{(57)}$ concept of information orientation was used. We conceptualise a 
CRM capability as a formative construct comprised of three items: (1) level of CRM related IT infrastructure, (2) human skills and experience converting data to customer knowledge and (3) business architecture (alignment of incentives, customer strategy and structure). In the marketing literature, Day and Van den Bulte ${ }^{(58)}$ and Day ${ }^{(59)}$ have used similar items to develop their customer relating capability construct. Most importantly, our study differs from prior work because we are concerned with the extent to which these first order capabilities are superior to the competition. To capture this effect we required respondents to compare each first order capability to their direct competition.

Rather than replicate a complex series of measures for managerial beliefs, respondents were asked to evaluate the extent to which they believe CRM will "improve productivity and competitive standing" on a five point scale. This construct was measured as a single item because the question reflects our interest in the existence of positive or negative beliefs and not their specific characteristics. As noted by Rossiter ${ }^{(60)}$ there is no problem in using a single item measure when respondents understand clearly that only one characteristic is being referred to in the question. These measures are referred to as "concrete singular" and can be captured adequately using single item measures.

A recent multi method study by Chandy, Prabhu et al. ${ }^{(61)}$ found that managerial beliefs and expectations are a potent indicator of technology adoption. The author has previously found managerial beliefs to be a highly significant indicator of IT performance and against this backdrop a seven item scale was developed. ${ }^{(9)}$ Illustrative examples of the questions posed are provided in Appendix A. 


\section{Analysis and Results}

A two-step approach to data analysis was performed that: (1) includes a detailed assessment of the measurement model; and (2) includes an analysis of the relationships between constructs.

\section{Validating the Measurement Model}

To detect non-response bias, tests on the distribution of returned questionnaires relative to the sample were undertaken. The results indicated no significant industry or size bias. Several approaches were used to control for common method bias. First, matched responses (i.e., more than one response from the same company) were received from $64 \%$ of the organizations in this study. Using these matched responses we created an average score for performance that is company specific. No significant differences were found between the individual responses and company measures. The results indicate a lack of any "general factor" in the data that might be associated with common method bias. Second, we used Harmon's ex post one-factor test to assess common method bias. ${ }^{(62)}$ Twenty-one distinct factors were needed to explain $91 \%$ of the variance in the measures used, with the largest factor accounting for only $12 \%$ of the variance.

To ensure the validity of each measure convergent and discriminant validity were examined. Exploratory factor analyses of the underlying questionnaire items indicated one dimension for each construct, making it legitimate to test for convergent validity. Composite reliability scores-a technique similar to Cronbach alpha scores-were obtained for each construct. The composite reliability scores are all above 0.8 and well above acceptable thresholds for reflective scores. Discriminant validity was also assessed by comparing the variance shared by constructs, as measured by the squared correlation between them, with the AVE by each constructs

measurement items. ${ }^{(63)}$ The correlation matrix in Table 1 shows that the square root of the construct's AVE—as shown on the diagonal elements - are greater than the corresponding off- 
diagonal elements. Thus, it is possible to conclude that each measure was tapping into distinct and different concepts.

\author{
$<$ Insert Table 1 here >
}

\title{
The Structural Model
}

In this study, structural equation modelling was used based on the partial least squares (PLS) technique. The advantage of PLS to this study is that unlike regression it does not assume equal reliability among all items. It is a more sophisticated technique that enables one to identify the

true direct, indirect and total effects of one variable upon another, and to test for significance. ${ }^{(64)}$ Additionally, PLS can work with small to medium sample sizes and does not assume multivariate normality in the data.

Two structural models were analysed in this study. The first model is a simple direct effects model where the primary aim is to test the relative affect of a superior CRM capability on bank performance $\mathrm{H}_{1}$. As expected, the main effects model (see Table 2) reveals a positive and statistically significant link between superior CRM capability and performance $(\beta=0.414$; $\mathrm{p}<0.000$ ). This result provides strong support for $\mathrm{H}_{1}$. It is interesting to note that the item loadings for superior CRM capability and weights for bank performance reveal a number of interesting insights. Positive and significant loadings are reported for all indicators with business architecture (i.e., incentives and structures) being the most important (0.856), followed by human skills and experience (0.815) and IT infrastructure (0.805). In the case of bank performance, all weights are positive with return on investment (0.854) scoring the highest, followed by reduced transaction costs $(0.767)$, sales growth $(0.725)$ and new product revenue (0.673). All path loadings are significant with observed t-values reported in Table 2. 


\section{$<$ Insert Table 2 here $>$}

In formulating and testing for moderation in PLS, one needs to follow a hierarchical process similar to that used in multiple regression where one compares the results of two models. ${ }^{(65)}$ Essentially, this means comparing one model without the interaction to another model using the interaction construct. Standardized indicators were calculated using SPSS 12.0.1 because likert scales were employed in this study (see ${ }^{(64)}$ for justification). For the analysis with the interaction construct (as depicted in Figure 2) it is necessary to include the two main effect constructs (i.e., customer relating capability and managerial beliefs), to assess how the moderator construct influences performance.

$<$ Insert Figure 2 here >

The standardized path estimate for the interaction construct shows that a change in the moderator construct (managerial beliefs) will influence the main construct (CRM capability) on the dependent variable (performance). More specifically standardized beta scores are 0.430 for CRM capability, -0.105 for managerial beliefs and the interaction effect is 0.01 , with a total $\mathrm{R}^{2}$ of 0.20 . Thus, this result implies that a one standard deviation decrease in managerial belief will not only impact performance directly by 0.105 , but it would also increase the impact of CRM capability to performance from 0.430 to 0.440 . As expected, the explained variance reported in the interaction model $\left(\mathrm{R}^{2}=0.20\right)$ is higher than that reported in the direct effects model $\left(\mathrm{R}^{2}=0.18\right)$. However, the change in $\mathrm{R}^{2}$ of 0.02 implies that the moderator (managerial beliefs) plays only a small role in the $\mathrm{CRM}$ - performance relationship. The small change in $\mathrm{R}^{2}$ is the best indicator of moderating effects ${ }^{(66)}$ and therefore, does not provide support for $\mathrm{H}_{2}$.

\section{Discussion and Theoretical Contributions}

In this section we assess the potential contributions of the study on the emerging capabilities and 
RBV of the firm in strategy and marketing.

\section{Managerial Implications}

The judgments managers make about how to deploy CRM programs is an important feature of overall bank performance. Interestingly, the lower relative importance of IT infrastructure stands in contrast to what the marketing divisions of companies like Siebel, Oracle and SAP would like us to believe. However, this finding is not new and validates existing "wisdom" in the literature where scholars conclude that, in order to be successful, organizations must focus less on technology and more on the managerial process within the firm. ${ }^{(58,59,67)}$

Nevertheless, this study clearly shows that IT infrastructure is a necessary capability as it does provide a basis for detailed customer information required to support modelling and informed human decision making. The study has shown that the skills and know-how possessed by staff is not widely distributed and can act a source of distinct competitive advantage. Conceptually, this finding supports Swanson and Wang's ${ }^{(68)}$ findings that know-how is an important driver of packaged software success.

Customer knowledge alone is no guarantee for success, however. Execution of these capabilities involves a series of internally consistent, integrated activities or processes that can be extremely challenging. These challenges are particularly acute in the banking industry and are a source of great frustration, as alluded to in this quote by a Director, Financial Services Company collected during a series of pre test interviews:

"Nothing is ever smooth. The biggest problem we have in the bank is implementing, you know, just getting the people to develop the systems is basically a pain in the backside. It just takes so long and we have been trying to get a new CRM system going for this all financial services type offering. We have gone 
around in circles the last two months, we still haven't got there and I think we are pretty frustrated by it all."

Our study shows that managers in the highest performing banks remain somewhat skeptical of the potential for CRM to improve productivity and competitive standing, which suggests that managers in general should be wary of a natural tendency to be overoptimistic about the benefits of CRM. For example, research in cognitive science ${ }^{(69)}$ has shown that managers who currently have high investment in assets (such as CRM infrastructure) are particularly likely to believe that these programs will provide benefits. The insight gained is that managers should be mindful of the challenges facing CRM execution. The firms that were most comfortable with CRM had a clear, unconstrained strategy aimed at where they wanted to go. Firms that were struggling with CRM initiatives were those that were allowing the technology to decide where they needed to go. As such, they were more likely to be befuddled by the options being presented to them by technology suppliers.

The Director, Investment Banking attributed their success with CRM to:

"we committed very substantial funds right up front to fund CRM-this is what there is to be spent. We succeeded in gaining consensus or a common understanding of where we wanted to go and the beauty of this is that we did not prevent some places from going ahead faster than others. The CRM model then is really to help the bank evolve into the next generation of investment banks, to be able to meet the demands of here and now."

\section{Limitations and Direction for Further Research}

As is the case with any study, this research has limitations that qualify our findings and present 
opportunities for future research. While it is often argued that cross-sectional designs are justified in exploratory studies that seek to identify emerging theoretical perspectives, this does not escape the inability of this type of design to fully capture causality. For this reason, the results of this study should be viewed as preliminary evidence that a superior CRM capability will influence bank performance. This highlights the now customary call for the use of longitudinal studies to corroborate cross-sectional findings and examine performance prior to and after a CRM program implementation. Additionally, it is possible that those companies that have been working longer on their CRM programs are, in turn, among the better performing companies. Longitudinal studies would provide the necessary insight required to evaluate this effect.

Another limitation is the relatively small sample size. Although, highly representative sampling was achieved-market share greater than $70 \%$ of Australian banks - the small sample inhibits further analysis. For example, the non significant impact of managerial beliefs on performance may be a reflection of the lack of low test power in the study. Power works against the moderating hypothesis reducing the ability to identify subtle effects. Interpretation of moderators based on interval scales is also difficult due to: variability in the linear transformations and/or confounding main and moderating effects. ${ }^{(66)}$ Future work based on larger samples and ration level scales would also allow one to test competing models for moderating effects. However, creating ration scales from managerial perceptions is not simple and requires advanced psychophysical scaling procedures. ${ }^{(70)}$ This type of analysis would be useful to capture the impact of firm heterogeneity in the way CRM is deployed within the banking sector.

Finally, one could reasonably argue that high performing banks benefit through reinvestment of profits. This feedback loop effect enables banks to devote considerable resources into CRM programs to ensure they are successful. Future work should seek to control for resource 
munificence, however, scholars should exercise caution in attempting to capture this effect. Potential problems arise with the way resources are measured because most extant studies seek to identify the availability of critical resources and capabilities by comparing successful companies with unsuccessful ones. Once these are identified, scholars have then sought to test if the resources and capabilities identified are indeed critical. Not surprisingly, the answer to this question is always a yes, making the theory unfalsifiable. ${ }^{(71)}$ To overcome this tautological problem scholars require measures of capabilities that are independent of their rent generation ability.

\section{Conclusion}

CRM suffers when it is poorly understood, improperly applied, and incorrectly measured and managed. Prior empirical work implies that more relationship building is not necessarily better, but rather building the right type of relationship is the key to performance improvement. In this study of industry leaders we show that a superior CRM capability does lead to improved performance. The first implication for managers is that CRM programs should be directed towards an adroit combination of capabilities that competitors may struggle to match. On this point the results are quite clear: high performing banks base their CRM program success on business structures first, human skills second, and IT third.

Bringing these capabilities together is not easy, but that is exactly why effective CRM can be a source of competitive advantage. A challenge that the senior manager of a global market leading bank acknowledged:

"until recently we have been somewhat restricted because we really haven't had the total customer relationship management and life cycle relationship management capabilities that we really needed to manage life cycle and to 
measure life cycle profitability with the accuracy required. Developing this capability has been extremely challenging." 


\section{References}

1. Khirallah K. CRM Case Study: Optimizing Relationships at National Australia Bank, Ltd. Needham, MA USA: Tower Group; 2001 January.

2. Reinartz W, Kumar V. The Mismanagement of Customer Loyalty. Harvard Business Review 2002;80(7):86-94.

3. Datamonitor, Siebel. CRM Spending has Failed Financial Services Organisations. In: The Customer Management Community; 2004.

4. Rigby DK, Reichheld FF, Schefter P. Avoid the Four Perils of CRM. Harvard Business Review 2002;80(2):101-109.

5. Payne A, Frow P. A Strategic Framework for CRM. Journal of Marketing 2005;69(10):167-176.

6. Kumar V, Reinartz WJ. Customer Relationship Management: A Databased Approach. New Jersey: John Wiley \& Sons; 2006.

7. Acedo FJ, Barroso C, Galan JL. The Resource-Based Theory: Dissemination and Main Trends. Strategic Management Journal 2006;27(7):621-636.

8. Barney JB. Firm Resources and Sustained Competitive Advantage. Journal of Management 1991;17(1):19-120.

9. Coltman T, Devinney TM, Midgley DF. E-Business Strategy and Firm Performance: A Latent Class Assessment. Journal of Information Technology 2007;21(4):1-15.

10. Coltman T, Dolnicar S. eCRM and Managerial Discretion. International Journal of e-Business Research 2007;3(2):41-56.

11. Hambrick DC, Finkelstein S. Managerial Discretion: A Bridge between Polar Views on Organizations. In: Cummings LL, Straw M, editors. Research in Organizational Behavior. Greenwich, CT: JAI Press; 1987. p. 369-406.

12. Drucker PF. The Practice of Management. New York: Harper and Row; 1954.

13. Fornell C, Mithas S, III FVM, Krishnan MS. Customer Satisfaction and Stock Prices: High Returns, Low Risk. Journal of Marketing 2006;70(1):3-14.

14. Reichheld F, Teal T. The Loyalty Effect. Boston, MA: Harvard Business School Press; 1996.

15. Langerak F. An Appraisal of Research on the Predictive Power of Market Orientation. European Management Journal 2003;21(4):447-464.

16. Reinartz W, Kumar V. On the Profitability of Long-Life Customers in a Noncontractual Setting. Journal of Marketing 2000;64(3):17-35.

17. Ray G, Muhanna WA, Barney JB. Information Technology and the Performance of the Customer Service Process: A Resource-based Analysis. MIS Quarterly 2005;29(4):625-653.

18. Ryals L, Payne A. Customer Relationship Management and Financial Services: Towards Information Enabled Relationship Marketing. Journal of Strategic Marketing 2001;9(1):1-25.

19. Carr N. IT Doesn't Matter. Harvard Business Review 2003;81(5):5-12.

20. Piccoli G, Ives B. IT-Dependent Strategic Initiatives and Sustained Competitive Advantage: A Review and Synthesis of the Literature. MIS Quarterly 2005;29(4):747-777.

21. Bharadwaj AS. A Resource-Based Perspective on Information Technology Capability and Firm Performance: An Empirical Investigation. MIS Quarterly 2000;24(1):169-196.

22. Zhu K. The Complementarity of Information Technology Infrastructure and E-Commerce Capability: A Resource-Based Assessment of Their Business Value. Journal of Management Information Systems 2004;21(1):167.

23. Zhu K, Kraemer KL. e-Commerce Metrics for Net-enhanced Organizations: Assessing the Value e-Commerce to Firm Performance in the Manufacturing Sector. Information Systems Research 2002;13(3):275-296.

24. Santhanam R, Hartono E. Issues in Linking IT Capability to Firm Performance. MIS Quarterly 2003;27(1):125-153. 
25. Rivard S, Raymond L, Verreault D. Resource-Based View and Competitive Strategy: An Integrated Model of the Contribution of Information Technology to Firm Performance. Journal of Strategic Information Systems 2006;15:29-50.

26. Watjatrakul B. Determinants of IS Sourcing Decisions: A Comparative Study of Transaction Cost Theory versus the Resource-based View. Journal of Strategic Information Systems 2005;14(4):389-415.

27. Wernerfelt B. A Resource-Based View of the Firm. Strategic Management Journal 1984;5(2):171181.

28. Grant RM. Toward a Knowledge-Based Theory of the Firm. Strategic Management Journal 1996;38(5):109-122.

29. Zander V, Kogut B. Knowledge and the Speed of the Transfer and Imitation of Organizational Capabilities:An Empirical Test. Organization Science 1995;6:76-91.

30. Davenport TH, Harris JG, Long DWD, Jacobson AL. Data to Knowledge to Results: Building and Analytic Capability. California Management Review 2001;43(2):117-137.

31. Davenport TH. Competing on Analytics. Harvard Business Review 2006;84(1):1-10.

32. Makadok R. Toward a Synthesis of Resource-Based and Dynamic Capability Views of Rent Creation. Strategic Management Journal 2001;22(5):387-402.

33. Baum JAC, Oliver C. Towards an Institutional Ecology of Organizational Founding. Academy of Management Journal 1992;39(10):1378-1427.

34. Schulz M. Limits of Bureaucratic Growth: The Density Dependence of Organizational Rule Births. Admin Science Quarterly 1998;43(4):845-876.

35. Leonard-Barton D, Deschamps I. Managerial Influence in the Implementation of New Technology. Management Science 1988;34(10):1252-1264.

36. Finkelstein S, Hambrick DC. Strategic Leadership: Top Executives and their Effects on Organizations. St Paul; MN: Printwise; 1996.

37. Henderson RM, Clark KB. Architectural Innovation: The Reconfiguration of Existing Product Technologies and the Failure of Established Firms. Administrative Science Quarterly 1990;35(1):9-30.

38. Tushman ML, Anderson P. Technological Discontinuities and Organizational Environments. Administrative Science Quarterly 1986;31(3):439-466.

39. Anderson P, Tushman ML. Technological Discontinuities and Dominant Designs: A Cyclical Model of Technological Change. Administrative Science Quarterly 1990;35(4):604-634.

40. Ajzen I. The Theory of Planned Behavior. Organizational Behavior and Human Decision Processes 1991;50(2):179-211.

41. Davis FD. Perceived Usefulness, Perceived Ease of Use and End User Acceptance of IT. MIS Quarterly 1989;13(3):318-339.

42. Mezias JM, Starbuck WH. Studying the Accuracy of Manager's Perceptions: A Research Odyssey. British Journal of Management 2003;14:3-17.

43. Index CSCC. State of Reengineering Report. Cambridge, MA: Forrester Research Inc.; 1994.

44. Manuel E, Arthur H, Daniel L, Jim` M. How to Rescue CRM. McKinsey Quarterly 2002;4.

45. Agarwal A, Harding DP, Schumacher JR. Organizing for CRM. The McKinsey Quarterly 2004.

46. Varadarajan PR. Strategy Content and Process Perspectives Revisited. Academy of Marketing Science Journal 1999;27(1):88-101.

47. Wind Y, Robertson TS. Marketing Strategy: New Directions for Theory and Research. Journal of Marketing 1983;47(Spring):12-25.

48. Day GS, Wensley R. Assessing Advantage: A Framework for Diagnosing Competitive Superiority. Journal of Marketing 1988;52(4):1-20.

49. Hunt SD. A General Theory fo Competitive Advantage: Resources, Competences, Productivity, Economic Growth. CA, Sage: Thousand Oaks; 2000.

50. Hunt SD, Morgan RM. The Comparative Advantage Theory of Competition. Journal of Marketing 1995;59(2):1-15. 
51. March JG, Sutton RI. Organizational Performance as a Dependent Variable. Organization Science 1997;8(6):698-706.

52. Bathelor. Australian Bank Competition Keeps Rates Low. In: Bloomberg.com; 2006.

53. Dess GG, Robinson RB. Measuring Organizational Performance: The Case of the Privately-Held Firm and Conglomerate Business Unit. Strategic Management Journal 1984;5:265-273.

54. Fryxell GE, Wang J. The Fortune Corporate "Reputation Index": Reputation For What? Journal of Management 1994;20(1):1-14.

55. Kaplan R, Norton D. The Balanced Scorecard. Boston: Harvard Business School Press; 1996.

56. Birley S, Westhead P. Growth and performance contrasts between 'types' of small firms. Strategic Management Journal 1990;11(7):535-557.

57. Marchand DA, Kettinger WJ, Rollins JD. Information Orientation: People, Technology and the Bottom Line. Sloan Management Review 2000;41(4):69-84.

58. Day GS, Bulte CVd. Superiority in Customer Relationship Management: Consequences for Competitive Advantage and Performance. In: Marketing Science Institute. Cambridge MA; 2002.

59. Day GS. Creating a Superior Customer-Relating Capability. MIT Sloan Management Review 2003;44(3):77-82.

60. Rossiter JR. The C-OAR-SE Procedure for Scale Development in Marketing. International Journal of Research in Marketing 2002;19(4):1-31.

61. Chandy RK, Prabhu JC, Anyia KD. What Will the Future Bring? Dominance, Technology Expectations and Radical Innovation. In: Marketing Science Institute; 2002.

62. Podsakoff P, Organ D. Self Reports in Organizational Research: Problems and Prospects. Journal of Management 1986;12(4):531-544.

63. Fornell C, Larcker DF. Evaluating Structural Equation Models with Unobservable Variables and Measurement Error. Journal of Marketing Research 1981;18(3):39-50.

64. Aiken LS, West SG. Multiple Regression: Testing and Interpreting Interactions. Newbury Park, CA: Sage Publications; 1991.

65. Chin WW, Marcolin BL, Newsted PR. A PLS Latent Variable Modeling Approach for Measuring Interaction Effects. Information Systems Research 2003;14(2):189-217.

66. Carte TA, Russell CJ. In Pursuit of Moderation: Nice Common Errors and Their Solutions. MIS Quarterly 2003;27(3):479-501.

67. Powell T, Dent-Medcalfe A. Information Technology as Competitive Advantage: The Role of Human, Business, and Technology Resources. Strategic Management Journal 1997;18(5):375405.

68. Swanson EB, Wang P. Knowing Why and How to Innovate with Packaged Business Software. Journal of Information Technology 2005;20(1):20-31.

69. Brunnermeier, Parker. 2003.

70. Birnbaum MH. Measurement, Judgement and Decision Making. San Diego, California: Academic Press; 1998.

71. Dutta S, Narasimhan O, Rajiv S. Conceptualising and Measuring Capabilities: Methodology and Empirical Application. Strategic Management Journal 2005;26(3):277-285. 


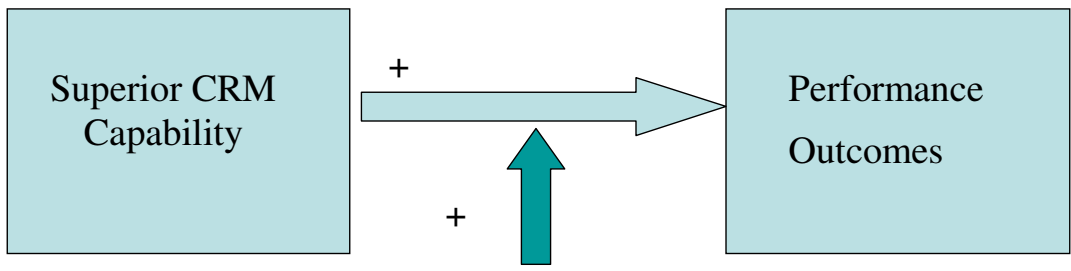

\section{Managerial Beliefs}

Figure 1 - Model and hypothesized relationships 


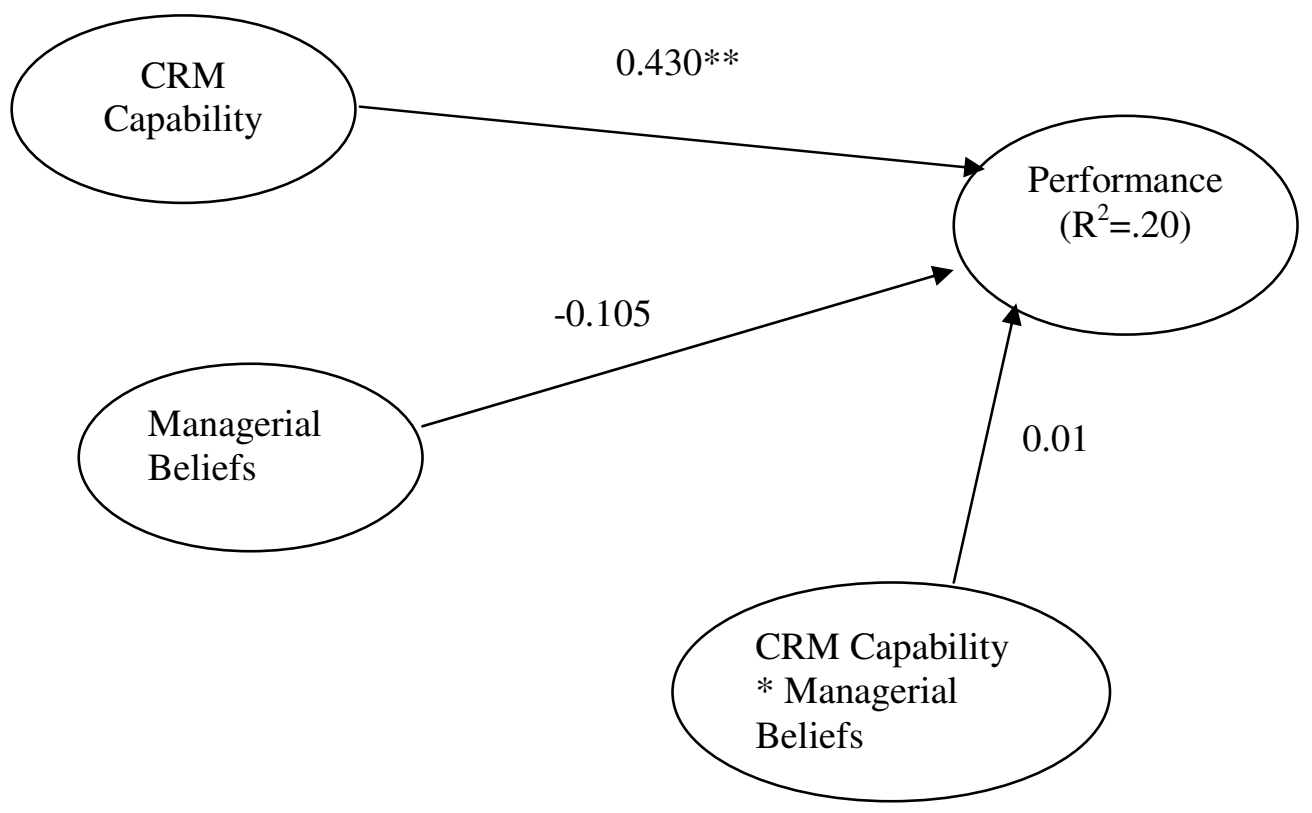

Figure 2 - Interaction effect model

$\mathrm{P}=$ value: $*<0.1 ; * *<0.05 ; * * *<0.001$ 
Table 1 - Correlation of Latent Constructs (diagonal elements are square roots of average variance extracted)

\begin{tabular}{|c|c|c|c|}
\hline & 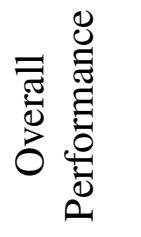 & 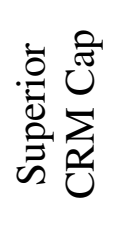 & 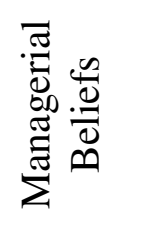 \\
\hline Overall Performance & 0.70 & & \\
\hline Superior CRM Capability & 0.35 & 0.81 & \\
\hline Managerial Beliefs & 0.11 & 0.31 & 1.00 \\
\hline
\end{tabular}


Table 2 - Direct Effects Structural Model

\begin{tabular}{|c|c|c|c|}
\hline & $\begin{array}{c}\text { Path } \\
\text { Coefficient }\end{array}$ & $\begin{array}{c}\text { Observed } \\
\text { t-value }\end{array}$ & $\begin{array}{c}\text { Significance } \\
\text { level }\end{array}$ \\
\hline CRM Capability & 0.438 & 2.347 & $* * *$ \\
\hline Human Skills and Experience & 0.815 & 4.014 & $* * *$ \\
\hline IT Infrastructure & 0.805 & 3.846 & $* * *$ \\
\hline Business Architecture & 0.856 & 10.759 & $* * *$ \\
\hline \multicolumn{4}{|l|}{ Performance $\left(R^{2}=0.18\right)$} \\
\hline Return on Investment & 0.854 & 14.937 & $* * *$ \\
\hline New product revenue & 0.673 & 3.430 & $* * *$ \\
\hline Reduced transaction costs & 0.767 & 7.540 & $* * *$ \\
\hline Sales growth & 0.725 & 7.178 & $* * *$ \\
\hline
\end{tabular}

$\mathrm{P}=$ value: $* * *<0.01$

n.a. = not applicable for single item measure 
Appendix A - Questions and Composite Reliability Scores

\section{Construct}

Performance (Composite Reliability $=0.842$ )

(Five point scale from Far Better to Much Worse)

Relative to the highest performer in your industry, how has your business performed over the last three years on return on investment (after tax)

Relative to the highest performer in your industry, how has your business performed over the last three years on new product revenue generation

Relative to the highest performer in your industry, how has your business performed over the last three years on sales growth

\section{Superior CRM Capability (Composite Reliability = 0.866)}

(Seven point scale from The Worst to The Leader)

Compared to your direct competitors, how do rate your organization's overall skills and experience at converting data to customer knowledge

Compared to your direct competitors, how do rate your organization's overall customer information infrastructure

How does your overall organizational architecture (i.e., alignment of incentives, customer strategy and structure) compare to your direct competitors?

Managerial Beliefs (Composite Reliability = 1.0)

(Five point scale from Strongly disagree to Strongly agree)

To what extent to you believe that CRM programs will improve productivity and the competitive standing of your firm 